\title{
Premises for an optimal model of managing the burden of financial losses stemming from damage to road infrastructure
}

\author{
Ewa Bagińska ${ }^{1, *}$, and Mateusz $\mathrm{Kosmol}^{1}$ \\ ${ }^{1}$ University of Gdańsk, ul. Bażyńskiego 6, 80-952 Gdańsk, Poland
}

\begin{abstract}
The empirical analysis of the distribution of risk related to the repair or replacement of road safety devices in existing performance-based maintenance contracts and the analysis of claims adjustment procedures indicate a certain imbalance in risk distribution between the road administrator and the entrepreneurs who have concluded road maintenance contracts, in particular performance based contracts. Relevant legal rules allow for a different, fairer distribution of the risk of suffering repair costs in certain damage scenarios. Insurance policy with a wide coverage of both property and liability risks appears as an optimal way of managing risks of losses to road infrastructure. Both contracting parties have an interest in obtaining first party insurance in the discussed field, although in practice it can be economical only to the General Directorate for National Roads and Motorways (GDDKiA). The law provides parties who suffered loss with a direct action against a traffic liability insurer of the wrongdoer who caused the damage.
\end{abstract}

\section{Introduction}

The paper discuses legal grounds and scope of the financial coverage of damage caused by road users to road safety devices. Damage to road safety devices can result from events having different nature. Most common are collisions of vehicles; less common events include devastation due to criminal acts, building catastrophes, natural calamities, etc. The person responsible for road maintenance is obliged to repair the damage without undue delay in order to keep the road safe for users. However, in certain cases the cost of the repair can be spread onto the persons legally liable for the damage or/and on the insurers liable to indemnify the loss under an insurance policy.

From the legal viewpoint different factual scenarios of liability should be taken account of. The scenarios point to potential defendants in a legal action for damages and help to identify situation in which the burden of damage will rest on the public administrator or a company to which the maintenance of a road was contracted out. The aim of the research is to suggest a more enhanced management of the burden of compensating losses stemming from damage to road infrastructure devices and the process of the indemnification of such losses. To this end, the role of insurance coverage is examined. At this point it is worth to

* Corresponding author: baginska@prawo.ug.edu.pl 
mention that in representative European countries there are no insurance models in effect at the moment. For instance, in Austria, Germany and Switzerland road safety devices are not insured under first-party policy insurance. In those countries the model of responsibility of the road owner or administrator for damage (Selbstversicherungsgrundsatz, Selbstfinanzierung) was adopted. The administrators usually claim indemnity from civil liability insurance policies of perpetrators. Similar situation can be observed in the United States. Thus, in this regard any exemplary model is missing.

The methodology of the research comprises methods commonly used in the legal science. Hence, it includes theoretical analysis of Polish and foreign literature, interpretation of legal rules, and the empirical analysis of the distribution of risk in performance-based maintenance contracts as well as claims (loss) adjustment procedures.

The authors have endeavoured to propose a legal, not economic, model of managing the burden of financial losses stemming from destruction or damage to road safety equipment. Hence 'optimal' in the legal sense means a fair and just distribution of parties' rights and duties.

\section{Managing the burden of financial losses through liability rules}

Four basic scenarios can be distinguished for the purpose of establishing the risk of civil liability (liability to compensate) for damage to road infrastructure. The first is the collision of the vehicle with a road safety device, which for which an identified car possessor can be held liable. In Polish law the Civil Code (article 436) imposes strict liability on the possessor of a vehicle for any damage resulted from the motion of the vehicle. It thus includes damage to the elements of road infrastructure. In the case of a collision of vehicles, which led to the destruction of the infrastructure, the liability is born by the car possessor was at fault.

The possessor may avail himself of three possible defences to strict liability: force majeure, exclusive fault of the person injured or exclusive fault on the part of a third person (see art. $435 \S 1$ in connection with art. $436 \S 1$ of the civil code). The first and the third are relevant for this discussion.

Force majeure is understood to mean an extraneous and extraordinary event, the effects of which could not be foreseen nor prevented. An occurrence triggering a car accident must thus be characterised by all the features in order to qualify it as force majeure. Usually it will cover natural phenomena such as flood, lightning, tornado, avalanche, earthquake or a sudden unexpected snowstorm. The unforeseeability of event should be seen objectively as inability to forecast a concrete situation and outcome of force majeure. The abstract anticipation of the phenomenon as such does not permit the conclusion of it being force majeure, if its consequences could not be foreseen or avoided. The category of "third person" comprises both another a user of a road and a person obliged to maintain safety of the road, such as state and self-government local authority or a company carrying out road works (the judgment of the Supreme Court of 28.12.1981, IV CR 465/81, OSN 5-6/1982, at 88). However, the bad condition of the road which can be attributed to the negligence of a person responsible for the road maintenance cannot be used as a defence to the liability of the car possessor as long as he should have known about that condition and have exercised due care (the judgment of the Supreme Court of 15 Sep. 1956, 4 CR 356/56, OSN 1957, at 58).

The court practice shows that it is difficult for the car owner to successfully defend his liability for damage stemming from a car accident [1]. However, each possessor of a car is obliged by law to take out a civil liability insurance for damages arising from traffic accidents (The law of 22.05.2003 on compulsory insurance, the Insurance Guarantee Fund and Polish Bureau of Traffic Insurers, Journal of Laws, no. 124, at 1152). When damage 
occurs an insurer pays compensation to an injured person each time civil liability attaches to an insured [2], within the limits of this liability and subject to the contractual ceiling of the coverage. The maximum guaranteed sum in cases of property losses is 1 million EURO with respect to one event covered by the policy and regardless of the number of injured people. The injured person may bring his claim directly to an insurer; hence she has actio directa against an insurer (Article $822 \S 3$ of the Polish Civil Code, Article 19 of the law on compulsory insurance, the judgment of the Supreme Court of 13.05.1996, II CZP 184/95, OSN 7-8/1996, at 91).

The risk of liability in a most typical case can thus primarily be managed through compulsory third party liability insurance. Insurance coverage can be triggered by any person who suffers financial loss (such as the cost of repair or replacement of road safety devices) that is in adequate causal link with the accident. The category of an injured person' includes the contractor responsible for the road maintenance, because civil liability rules apply to everyone and protect everyone who has been injured on equal footing. [2]

A variant of the above factual scenario includes a situation when the car possessor has been identified, but uninsured. As far as uninsured cars are concerned, the Insurance Guarantee Fund covers the liability for property damage.

In the second basic scenario, that is when the car possessor or driver can be absolved from the liability, the risk of damage to road infrastructure shifts to the owner or administrator of the road. The latter, in turn, usually transfers the risk to the contractor responsible for the road maintenance, who will incur the expenses needed to return the infrastructure to its previous state.

The same result is in the third scenario, namely when the wrongdoer who escaped from the accident site cannot be identified. As far as unidentified cars are concerned, the liability for property damage in only partially covered by the Insurance Guarantee Fund (serious personal injury must coincide with damage to property). In Poland, however, over $90 \%$ of users of national roads who caused damage to the road infrastructure are identified due to the toll system and road monitoring, therefore we will focus on the possible ways of the management of financial losses in the second scenario.

\section{The distribution of risk related to the repair or replacement of road safety devices in performance-based maintenance contracts}

Presently in Poland, the government follows the model of managing public national roads through Performance-based Road Management and Maintenance Contracts (hereafter Performance-Based Contracts, PBC), whose design, however, varies from region to region. Performance-Based Contracts define minimum conditions of road traffic assets that have to be met by the contractor, instead of the processes to achieve the outcome. [3] For reasons linked to the often-repeated argument of scarce financial resources and broad public tasks, governmental authorities are likely to shift a significant portion of the risk of repairs or replacement of damaged road safety equipment on public roads to private parties who have contracted to maintain those roads. [4]

The empirical analysis of the contents of the performance-based contracts shows that governmental agencies sometimes go too far in trying to shift risks to contractors, for example, by forcing the latter to bear all the risk of ultra severe and unanticipated weather conditions in a given area, such as hurricane, subsidence, landslide, rockslide, or earthquake.

In the said contracts agreed payments are flat lump sums, which can be reduced, based on the level of compliance of the contractor with the performance standards defined 
in the contract. Hence, even if the risk of damage exceeds the risk, which could reasonably be apprehended by the contractor at the time of the conclusion of a PBC, the latter is usually not allowed to ask for the increase of the contractual fee for the extra services and work performed. Hence, the analysis of the distribution of risk related to the repair or replacement of road safety devices in existing performance-based maintenance contracts indicates a clear imbalance in the risk distribution between the contractual parties: a road administrator and a private entrepreneur. Despite the fact that the contractors use efficient methods of seeking persons who are liable for damage to road structures, compensatory claims against respective civil liability insurers are filed by the governmental agency itself.

In the light of the above, we are of the opinion, that in the case of the realisation of certain risks a PBC contract should reflect the additional amount of works and services executed, especially when the financial losses of the contractor can be linked to extraordinary events that exceed the ordinary contractual risks. [3]

The risk of damaging road equipment elements can be divided, for the purpose of this discussion, into risks, which stem from natural events and the so-called man-made risks. The first group includes unexpectedly severe weather (hurricane, storm) or environmental problems, such as subsidence, rockslide, as well as earthquake, flood and landslide. Manmade risk, on the other hand, i.e. those risks which involve human element, and embrace for example unanticipated poor quality of construction or defects in design of road safety equipment, unexpected traffic growth, terrorists' attack. A clear division of risks in a contract is a proper legal method to ensure fair and balanced contracts. However, in present social and economic conditions in Poland, such a method seems to be insufficient to reach the said goal.

\section{Managing risks of losses to road infrastructure through insurance}

Although presently a small part of the financial losses due to the damage to road safety devices is already compensated under the property insurance policy taken by the Polish central governmental agency responsible for public roads, namely the General Directorate for National Roads and Motorways (GDDKiA), we recognize that an insurance protection should be better developed with respect to the discussed losses.

The concept of an optimal solution of the managing risks of losses to road infrastructure through insurance assumes that the burden of covering the damage should eventually be shared by: the perpetrator (usually the vehicle possessor who caused the damage by a collision), the owner or administrator of the road and the PBC contractor. To the extent possible, the burden may be transferred to the insurance company and/or companies.

It should be emphasised that both parties to a PBC have an insurable interest in obtaining first party insurance regarding the elements of the road infrastructure. [5] The insurance policy of the whole national road infrastructure may and is of course obtained by its administrator (GDDKiA) on behalf of the State as the owner. However, insuring property is not conditioned on its ownership; any entity who has a legitimate interest in maintaining given road assets, even it does not have its ownership or other proprietary right to it, can obtain a first party insurance. [5,6]Thus, as a contractor who under the PBC contract is the actual holder of possessed road assets and suffers a financial burden of repairs or replacement of damaged items, has a clear insurable financial interest. In insurance law more than one person can have an insurable interest in the same property and their interests can overlap and co-exist. [7] 
We recognize that an insurance program with a wide coverage of both property and liability risks can appear as most suitable way of managing the risk of financial losses stemming to damage to road infrastructure.

The fundamental elements of the optimal road infrastructure insurance model are the following:

\subsection{The recognition of the insurable interest in property insurance (discussed above)}

Although, in practice, property insurance can seem economical only to the General Directorate for National Roads and Motorways (GDDKiA), as representing the owner of public roads, the interest of the $\mathrm{PBC}$ contractors will be limited to certain regions or areas, covered by the relevant PBC.

\subsection{The optimal insurance program.}

The optimal insurance program should cover both the risk of damage to property (property insurance) and the risk of civil liability (liability insurance). Losses compensated as a part of the property insurance policy may result in a risk of civil liability of the entity responsible for causing them (for example third parties: the driver or the PBC contractor itself). Comprehensive civil liability insurance will ensure real protection, if the addressee of compensatory claims will have a correctly designed third party liability insurance contract. It ought to be considered whether such a general policy (the so-called insurance product or insurance program) should be concluded in the co-insurance formula. The latter formula means that more than one insurer share the risk; it thus provides 'cumulative' insurance coverage. [2]

\subsection{The types and levels of insurance risk.}

It is important and necessary to establish the limits of risk from which the contractors shall be insured, and those, which should be insured by the governmental entity. Risks are indicators of the insurable interest.[7,8] Mention should be made at this point that the contractual imposition of an insurance obligation on a PBC contractor is permitted. Proposed risk levels are the following:

The first risk level - it embraces damage resulting from typical phenomena (for instance road collisions) not exceeding the average measure and typical (normal) weather conditions.

The second risk level includes:

1) Damage resulting from severe weather phenomena, which, however, in Poland do not have an extraordinary character, but can cause serious damage, such as a storm which causes subsidence and collapse of a road embankment;

2) Damage caused by catastrophic weather phenomena, which are, however, predictable, for example flood in flood plains, as well as biological and chemical contamination.

3) Damage of a considerable size caused by human element (e.g. due to lack of proper marking), although they are foreseeable and preventable.

The third risk level - includes catastrophic risks, i.e. damage caused by force majeure, originating in natural phenomena, however, that do not occur in a given area (e.g. tectonic movements), an man-made risks (e.g. terrorist attack, war, acts similar to war, social unrest), as well as the risk of damage resulting from design errors and/or the use of 
defective materials for the production of road safety equipment.

It should be made clear that in the above categorization we have not exhausted all the possible damaging events. There are cases that do not fit uniquely into any of the above categories of risks; or the damage is the result of two or more causes.

The key question is how the insurance obligation shall be distributed. Presently in Poland, contractors are not insured against any of the above-mentioned risks. On the other hand, GDDKiA is insured against all risks (the so called 'all risks insurance'), however, capped at a relatively low sum guaranteed for a given year.[6,9] As a result, after the first few months of each year the sum will have been consumed. In 'all risks' insurance the cover is loss, destruction or damage by any cause not specifically excluded. [9] 'All risk' insurance although offering a wide protection, typically excludes damaging events resulting from terrorist threats, warfare or acts similar to war, riots, change in water table level, pollution or contamination, mechanical or electrical breakdown or derangement, heave or landslip or the normal settlement or bedding down of new structures. It should be underlined that the exclusions may depend on the type of property being insured. [9] On the other hand, PBC should define such events as force majeure, which affects the scope of liability of the contractor under a PBC contract.

Although, theoretically speaking, every risk can be insured [10], the first level of risks will probably generate too high costs and thus it will be economically unfeasible for a PBC contractor to obtain an insurance policy. As to the second level of risk, the contractor could insure the interest in the road assets for the safety of which he is contractually responsible, while in the governmental agency could still insure the global road infrastructure from discussed risks. Double protection is allowed and the civil code provides for the rules on the sharing of indemnity in article $8241 \S 2$ of the civil code. [2] Finally, it should be underlined that the governmental agency can still seek insurance protection from the third level of risk. Mention at this point should be made of the role of the State in ensuring financial protection against the terrorist risk, riots, and similar events. Shifting of a part of the liability risk from the administrating authority to other authorities, e.g. to a special fund could be an option. [10,11]

\subsection{The connection between property insurance and third party liability insurance.}

There should be a close connection between the claims adjustment under property insurance and under third party liability insurance of vehicle possessors. Legally speaking, there is no obligation to liquidate damage to the road infrastructure from the property insurance policy. The damage can be repaired by the possessor of a motor vehicle who caused the damage or by its liability insurer. The law provides the injured parties with a direct action against a traffic liability insurer of the wrongdoer who caused the damage. Claims adjustments in insurance practice should focus on the complementary coverage of first party insurance (property insurance) and third party insurance (i.e. traffic liability insurance), with the precedence of the latter.

\subsection{The compensation payment from third party liability insurance.}

Under third party liability insurance the damage may be paid directly into the bank account of the contractor, who actually incurred the costs of repair of the damaged road component. In practice, because traffic liability is subject to compulsory third party liability insurance, the aggrieved party, here the contractor who repaired the infrastructure, may direct his claims for compensation straightway to the perpetrator's insurer, which has been an 
accepted principle in Polish law not only in relation to compulsory third party liability insurance of vehicle possessors, but also for all third party liability insurance.

\subsection{The reimbursement (recourse) claims.}

A suitable protection method against an insurer's recourse claims (referred to as an 'insurance subrogation'- see Article 828 of the civil code) would be a protection model, which combines property insurance with a properly designed third party liability insurance. This problem should also be directly and precisely regulated in insurance contracts, in order to avoid situations in which the insurer, after the liquidation proceedings, demands reimbursement from the entity responsible for the damage, which may be contractor or even the governmental entity itself (for its own negligence).

\subsection{The settlements between insurance companies.}

In the context of road infrastructure insurance programs, the cases of double insurance may occur, which may be beneficial from the point of view of insured entities, because it strengthens their certainty that the damage will be fully compensated, even if the sum insured in one policy will be lower than the damage suffered. It should, however, be underlined that mutual settlements of insurers against double insurance - as regulated by law - should not be subject to contractual regulations in PBCs. Such provisions would have no effect on insurers under articles $824-824^{1}$ of the civil code. Moreover, recourse agreements (also called 'knock for knock' contracts/provisions) shall be concluded neither between GDDKiA and contractors, nor between the insurers themselves. [2] The practice of signing knock for knock contracts/provisions is uncommon in insurance markets. Such agreements are limited only to the area of insurances in the field of motor vehicles liability. $[9,12]$ Knock-for-knock agreements were also criticized in the literature. [13]

\section{Conclusions}

In this paper we have argued that a contractual instrument, based on the parties' autonomy, is best suited to establish an optimal allocation of risks. However, as the government is typically more interested in shifting a significant portion of the risk of repairs of road safety equipment to the contractor and in including its coverage in the contractual remuneration, it is necessary to rethink the terms of PBCs contracts, in order to allow a different, fairer distribution of the risk of cost in certain damage scenarios. One of the modifications could be an explicit contractual recognition of a direct recourse claim by the $\mathrm{PBC}$ contractor to the insurer who covers civil liability of the wrongdoer. Indeed, the most favourable method for a public road administrator would seem to be the transferring of the burden of compensation to insurers, among others by way of providing the persons who suffered damage with a direct action against an insurer.

The first-party insurance of road infrastructure should be considered as a legal instrument available not only to the State as the roads' owner, but also to the contractors. Its coverage is supplementary to third-party liability traffic insurance.

In order to achieve an optimal protection through insurance and contracting three levels of damage risk can be recognized and their coverage should be apportioned between the interested parties. 
This paper was prepared under the joint venture project, called RID 3B (Development Innovation Road) financed by NCBiR (The National Research and Development Centre) and the General Directorate for National Roads and Motorways (GDDKiA), Contract no DZP/RID-I67/12/NCBR/2016.

\section{References}

1. K. Ludwichowska, Civil and insurance liability for car accidents (in Polish) (Dom Organizatora TNOiK, Toruń, 2008)

2. E. Kowalewski, Commercial insurance law (in Polish) (Branta, Bydgoszcz-Torun, 2006)

3. A. Gajurel, Performance-Based Contracts for Road Projects, Comp. Anal. 29 pp. 1159 (2014). doi:10.1007/978-81-322-1302-4

4. K.. Oliphant, The liability of public authorities in comparative perspective, in: K. Oliphant (Ed.), Liabil. Public Authorities Comp. Perspect., (2016)

5. S. Byczko, Insurance Interest. Legal Aspects (in Polish), pp. 173-175, 249 (2013)

6. K. Malinowska, Risk management in property insurance, in: M. .Serwach (Ed.), Insur. Risk. Sel. Issues Theory Pract. M Serwach (in Polish), (Lodz, 2013)

7. E. Kowalewski, Introduction to the theory of insurance interest, Insur. a Mark. Econ. 3 (1997)

8. E. Kowalewski, Risk in human activity and the possibilities of its limitation, in: T. Sangowski (Ed.), Commer. Insur., (2001)

9. C. Bennet, Dictionary of insurance (London, 1992)

10. G. Wagner, (Un)insurability and the choice between market insurance and public compensation systems, in: W.H. van Boom, M. Faure (Eds.), Shifts Compens. between Priv. Public Syst., (Springer, Vienna/New York, 2007)

11. M. Faure, T. Hartlief, Financial Compensation for Victims of Catastrophes (Springer, Vienna/New York, 2006)

12. N. Lawrence, The insurance business, Part 1, Polish Edition, 79 (Warsaw, 1992)

13. W. Warkało, Compensation liability. Functions, types, boundaries (in Polish) (Warsaw, 1972) 